\title{
ROLE OF PASSIVE TECHNIQUES TOWARDS ACHIEVING ENERGY- EFFICIENCY IN HIGH DENSITY DEVELOPMENTS -A COMPARATIVE ANALYSIS BETWEEN STAND-ALONE HOMES AND MULTI-FAMILY RESIDENTIAL DWELLINGS
}

\author{
Anup Naik \\ Department of Architecture \\ BMS College of Architecture, Bangalore, India
}

\section{INTRODUCTION}

Almost 55\% of the world population (i.e., 4.2 billion people) resides in cities, with the percentage estimated to increase to $70 \%$ by 2050 . According to the handbook of urban statistics, India is urbanizing rapidly with a growth of $2.76 \%$ in urban population (377.1 million inhabitants) from 2001 to 2011. The latest number of inhabitants residing in Indian cities has risen to $34.47 \%$ of its total population as per a report made in 2019 by world bank. The Indian urban population has seen a constant growth of $2.5 \%$ per annum, at an average, since the late 90 's. More than half of the total population will reside in urban regions of India by 2050 .

In this scenario of urban development in India the land available for construction is reducing rapidly, bringing multiple issues to light, both at, macro and micro level. The need to accommodate increasing population in limited urban space builds tremendous pressure on the natural resources - majorly on the availability of land. With increasing population, development and construction the natural ground coverage is reducing rapidly. This in return affects two phenomenon - the ecological system of the region and heat island effect. This further leads to increasing environmental temperatures, and hence adverse effects of climate change, due to immoderate reflection of sunrays from artificial and man-made surfaces.

\author{
Mamatha P. Raj \\ Department of Architecture \\ BMS College of Architecture, Bangalore, India
}

These increasing temperatures not only are responsible for bigger environmental issues but also effect the indoor ambience and human comfort in a built space. Along with increasing temperatures and inappropriate design of a space additional energy is consumed to maintain internal environment of a closed space. Construction industry in India consumes, approximately, $30 \%$ of the total energy with residential buildings alone accounting for $70 \%$ of it. The energy consumed can be segregated further into three parts, first for construction of the space, second for maintenance of the space and third for destruction of the space. This consumption of energy further leads to emission of harmful gasses leading to climate change thus forming a vicious cycle of climate change due to excessive energy consumption and increased energy consumption to combat impacts of climate change.

Heat Island effect caused due to reducing natural ground cover and increased built structures is a major cause of changing climate and needs a sensitive approach in order to reduce its adverse impact on the environment. Development is inevitable, thus this issue of reducing natural ground and increasing temperatures should be dealt with a sensitive perspective to achieve sustainability. This paper looks at a comparative analysis of two case studies one with higher natural ground cover (or higher built to unbuilt ratio) and other with a larger built footprint (or lower built to unbuilt ratio) - in order to understand the innovation in design as well as technology to achieve sustainability in either of the 
cases. This paper is part of a larger thesis which focuses on a passive-right approach towards sustainability hence, this paper highlights passive techniques considered in the below discussed case studies to achieve a comfortable indoor environment.

\section{CASE STUDIES}

\section{A. Single Unit Housing - Bungalows}

This segment of simulations looks at case examples from present day construction in Bangalore. A variety of samples are considered aiming towards covering all the major typologies seen in the city and demanded by the residents ${ }^{1}$. The case examples considered exhibit a combination of old and new techniques used to achieve sustainability, thus giving this research an insight on the practical feasibility of vernacular principles in present times, affordability of modern green technology and finding a right balance between the two in order to achieve affordable and sustainable design principles as a conclusion to this research.

\section{Villa House with Courtyard}

Typical Courtyard house

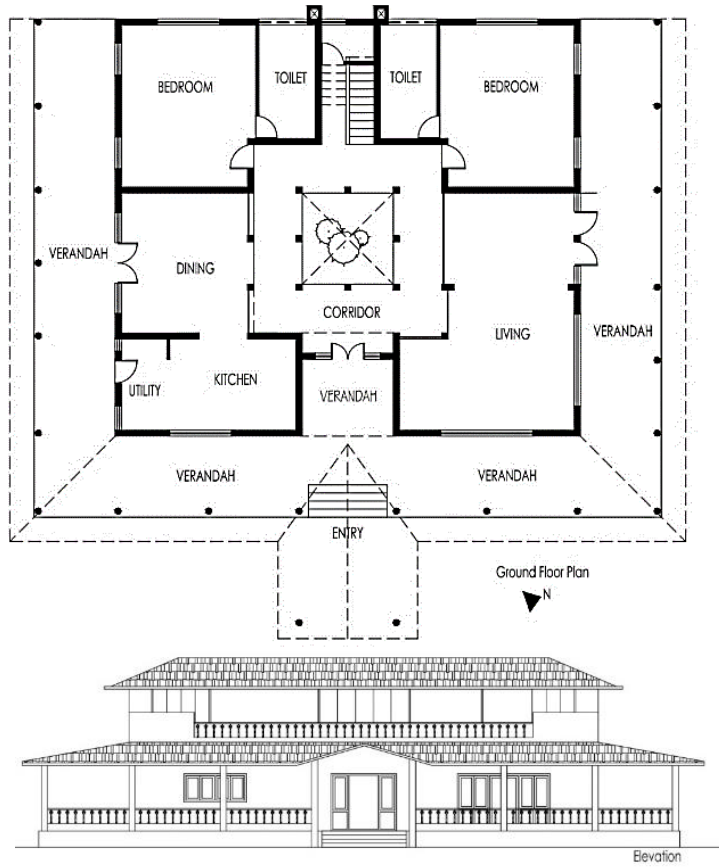

Figure 1: Plan and Elevation of the Courtyard House Source: Author

\footnotetext{
${ }^{1}$ The needs and aspirations of Banglorians are discussed above in Chapter 3 based on a survey conducted in the city.
}

An independent two-storeyed bungalow on a large open plot, with a central courtyard and peripheral veranda. Huge trees planted on the southern and south-western sides of the plot block direct sunlight harsh, late afternoon sunrays - and another row of trees along the north-eastern side, blocking the noise and pollution coming from the adjoining road as well as maintaining a natural curtain of privacy. The built structure is insulated with multiple layers of natural envelope forming approximately $85 \%$ of the total plot area.

The bungalow is aligned to the plot which is oriented along the north-western and south-eastern axis (almost tending towards the East- West axis). The built form is squarish in shape and equally exposed to external factors on all directions.

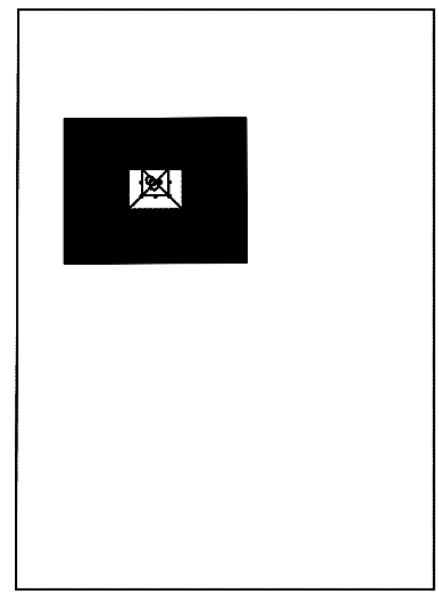

Figure 2: Built to Unbuilt diagram for Courtyard House.

Source: Author

A typical layout with courtyard in the centre and rooms along the circumference light up the rooms with diffused sunlight as well as promote air circulation thus making the indoor ambience comfortable with a minimal to no use of energydriven systems. The major advantage here is availability of land which offers an opportunity to insert elements which help to increase natural light and ventilation. Majority of the land is left unbuilt intact with its natural ground further decreasing emission of environmentally harmful gases due to heat island effect and positively impacting the surrounding environment. 


\section{International Journal of Engineering Applied Sciences and Technology, 2021 \\ Vol. 5, Issue 12, ISSN No. 2455-2143, Pages 280-290 \\ Published Online April 2021 in IJEAST (http://www.ijeast.com)}

Use of local materials like clay tiles, stabilised earth blocks, non-forest timber ${ }^{2}$ accompanied with modern designs, material combinations and technologies giving the end product an improved finish. Services like utility, staircase and toilet are placed on the southern and western lines of the house to reduce internal heating.

\section{B. Low Rise Apartment}

As the space crunch increase with unavailability of land, bungalows or villas became very expensive as the land cost increased. Slowly people moved towards building housing units vertically, hence lowrise buildings containing 4-6 floors started to evolve in and around the city.

\section{Typical Multi-Tenanted Scheme ${ }^{3}$}

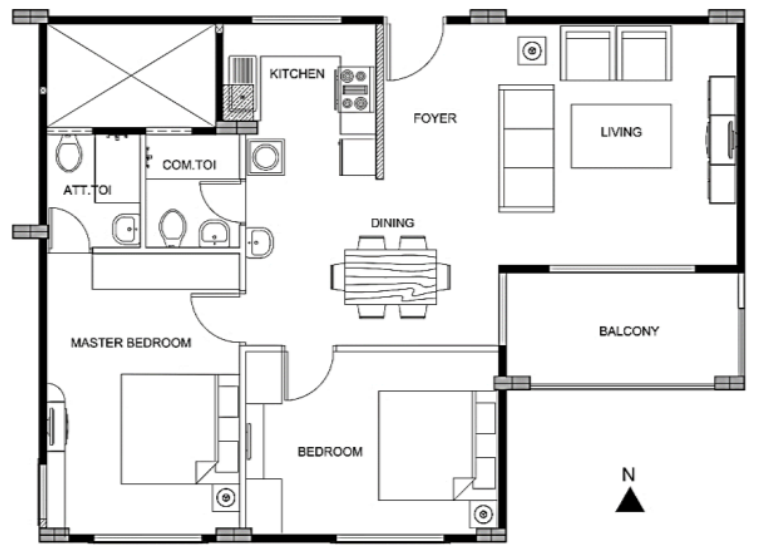

Figure 4: Typical Floor Plan of the Scheme Source: Author

This is one of the most discussed structure for achieving sustainability in a multi-tenanted scheme with multiple levels in Bangalore. This is a low-lying structure with six floors plus the ground.

This apartment building is famous for its extensive use of renewable energy to meet the energy requirements of the residents. The entire terrace area is used for organic farming which provides the members with basic daily supply, solar panels and windmills which helps meet the user's energy demands. Also drain water is adequately processed in the apartment premises and reused for the watering of landscape on the ground floor and in toilets of the

\footnotetext{
${ }^{2}$ Non-Forest Timber is the plantation timber which is specially grown for construction purposes - ecology isn't harmed if this timber is used.

${ }^{3}$ Typical Scheme considered here is Asset Aura constructed in Bangalore.
}

apartments ${ }^{4}$. This recycled and treated water is used for the organic farm on the terrace as well, thus minimising the water usage. All the farming done here is in coir or cocopeat, which is light in weight and does not add much dead weight to the building. This prevents the building's structural elements from becoming bulky and heavy.

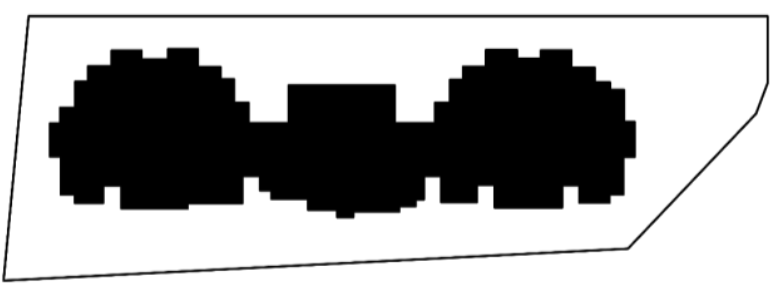

Figure 3: Built to Unbuilt diagram for the Scheme Source: Author

Also drain water is adequately processed in the apartment premises and reused for the watering of landscape on the ground floor and in toilets of the apartments. This recycled and treated water is used for the organic farm on the terrace as well, thus minimising the water usage. All the farming done here is in coir or cocopeat, which is light in weight and does not add much dead weight to the building. This prevents the building's structural elements from becoming bulky and heavy.

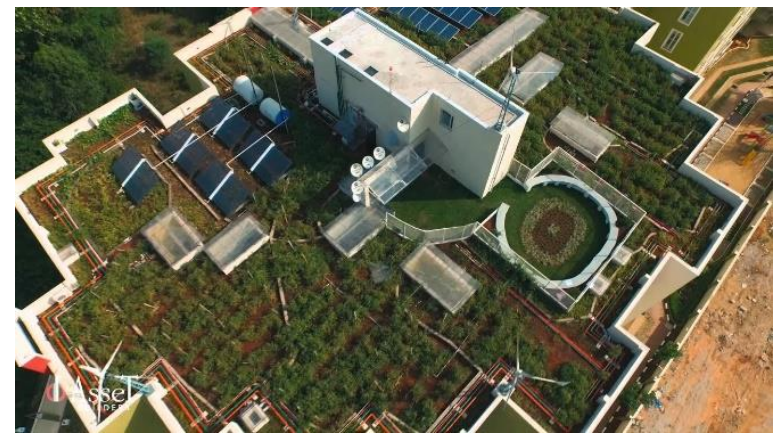

Figure 5: Image showing the utilization of the terrace space in the considered Scheme Source: Author

\footnotetext{
${ }^{4}$ Water as a factor is not discussed in detail as the main thesis and this paper are majorly focused on energy consumption.
} 


\section{INFERENCES}

Table 1: Comparative inferences derived from the above case studies.

\begin{tabular}{|c|c|c|}
\hline \multicolumn{3}{|c|}{ Geographical factors and Material (earth) } \\
\hline & Courtyard House & Multi-Tenanted Scheme \\
\hline Natural Topography & $\begin{array}{l}\text { Flat land, with } 80 \% \text { natural ground used to } \\
\text { retain the local topographical features of the } \\
\text { site. } \\
\text { The landscape becomes visually prominent in } \\
\text { the project considered. The earthy materials } \\
\text { used fade the distinction line between built } \\
\text { and unbuilt, merging nature with man-made } \\
\text { flawlessly. }\end{array}$ & $\begin{array}{l}\text { This is located in the city of Bangalore } \\
\text { on a flat land. With time the land } \\
\text { availability has been reduced as well as a } \\
\text { shortage of water has hit many parts of } \\
\text { the city. } \\
\text { Along with natural landscape on the } \\
\text { ground, this example considered has } \\
\text { gone a step ahead with setting up an } \\
\text { organic farm on its terrace. }\end{array}$ \\
\hline Climatic Conditions & $\begin{array}{l}\text { A multi-layered insulation from the external } \\
\text { climate is seen here. The outermost layer } \\
\text { being open natural ground with thick canopy } \\
\text { (wherever required), then the verandas going } \\
\text { around continuously on three sides, an } \\
\text { internal corridor which lines along an open } \\
\text { space and innermost being the courtyard with } \\
\text { trees offering a screening from harsh sun and } \\
\text { wind. } \\
\text { Extended overhangs double-up as shading } \\
\text { device for all types of openings along the } \\
\text { facades exposed to external conditions. }\end{array}$ & $\begin{array}{l}\text { The farm and solar panels on the terrace } \\
\text { reduce heat gain. The niches created in } \\
\text { design mutually shade the exterior } \\
\text { surfaces from sun. }\end{array}$ \\
\hline Orientation & $\begin{array}{l}\text { The bungalow is squarish in shape with } \\
\text { almost similar length and breadth dimensions, } \\
\text { aligned along the north-western and south- } \\
\text { eastern axis (tending towards the East- West } \\
\text { axis). } \\
\text { The built structures are aligned to the plot } \\
\text { avoiding formation of odd shaped landscape } \\
\text { areas (considering aesthetics and principles of } \\
\text { vastu). }\end{array}$ & $\begin{array}{l}\text { The entire scheme is aligned along the } \\
\text { North-South axis with maximum } \\
\text { apartments facing east and west } \\
\text { directions. The sample apartment } \\
\text { considered here is squarish with three } \\
\text { sides exposed to the exterior. }\end{array}$ \\
\hline Surrounding Context & $\begin{array}{l}\text { A busy road runs along the northern boundary } \\
\text { of the plot - which is lined with dense foliage } \\
\text { of plantation forming a natural screen from } \\
\text { the pollution, noise and strangers passing by. } \\
\text { The southern boundary of the plot is shared } \\
\text { with a stud farm - which is kept clear for } \\
\text { expanding views from the bungalow. }\end{array}$ & $\begin{array}{l}\text { This apartment is located in a typical } \\
\text { residential setting surrounded by other } \\
\text { residential apartments. }\end{array}$ \\
\hline Local vegetation & $\begin{array}{l}\text { A local variety of plants is used for } \\
\text { landscaping thus supporting surrounding } \\
\text { ecology. Along with maintaining the local } \\
\text { creatures, it also benefits the residents. }\end{array}$ & $\begin{array}{l}\text { Plants and crops grown on the ground } \\
\text { and terrace respectively are local to the } \\
\text { region, thus require low maintenance. }\end{array}$ \\
\hline
\end{tabular}




\begin{tabular}{|c|c|c|}
\hline Nature of Material & $\begin{array}{l}\text { All the material used for construction are } \\
\text { earthy materials obtained from natural and } \\
\text { environmentally sound resources or } \\
\text { techniques. } \\
\text { All the material used is procured from the } \\
\text { surrounding locality lying in a radius of not } \\
\text { more than a few hundred kilometres. }\end{array}$ & $\begin{array}{l}\text { The material used are conventional } \\
\text { synthetic materials. }\end{array}$ \\
\hline Local material used & $\begin{array}{l}\text { Locally available material like clay, lime and, } \\
\text { timber is used, made by companies in the } \\
\text { surrounding villages, thus promoting the art } \\
\text { of local skilled labour. }\end{array}$ & --- \\
\hline $\begin{array}{l}\text { Alternative } \\
\text { Construction materials }\end{array}$ & $\begin{array}{l}\text { Hollow bricks instead of solid bricks is used } \\
\text { thus reducing the total material consumed } \\
\text { during construction. This vacuum created } \\
\text { within a brick also forms an additional layer } \\
\text { of insulation from external weather. } \\
\text { Plantation timber or also known as non-forest } \\
\text { timber is used which protects forests from } \\
\text { unmeasured destruction for construction } \\
\text { industry. }\end{array}$ & --- \\
\hline Reusable materials & $\begin{array}{l}\text { The timber used as columns in the verandas, } \\
\text { corridors and as the support system } \\
\text { throughout the house can be reused owing to } \\
\text { the long life of wood. } \\
\text { All clay items can be recycled - if done } \\
\text { correctly - and reused, chipped bricks can be } \\
\text { used as elements in landscape, finer particles } \\
\text { can be used as sand or it can be completely } \\
\text { crushed and used to cast new construction } \\
\text { material (brick, roof tile, etc.). }\end{array}$ & --- \\
\hline \multicolumn{3}{|l|}{ Energy-efficiency (fire) } \\
\hline$\%$ of openings & $\begin{array}{l}\text { Western elevation has the highest percentage } \\
\text { of openings - } 40 \% \text { - mostly for services and } \\
\text { bedrooms which are used rarely and, in the } \\
\text { night, respectively. Large openings in the } \\
\text { bedrooms open to external views in the } \\
\text { morning - when the sun is not harsh. } \\
\text { The northern and southern elevations have } \\
25 \% \text { and } 20 \% \text { of wall window ratio, thus } \\
\text { opening the common spaces to exterior views } \\
\text { and diffused sunlight and air movement } \\
\text { throughout the day. } \\
\text { The eastern side has } 10 \% \text { of ratio, as the main } \\
\text { entry, porch and verandas are on this façade. }\end{array}$ & $\begin{array}{l}\text { An average of } 30 \% \text { of wall window ratio } \\
\text { is seen on all the exposed sides. }\end{array}$ \\
\hline Material of openings & $\begin{array}{l}\text { All the openings have an aluminium window } \\
\text { frame and normal float glass having a U- }\end{array}$ & $\begin{array}{l}\text { UPVC frames and modified single LOW- } \\
\text { E glass which have a U-value of } 2 \text { and }\end{array}$ \\
\hline
\end{tabular}




\begin{tabular}{|c|c|c|}
\hline & $\begin{array}{l}\text { value of } 0.57 \text { and } 2 \text { respectively. } \\
\text { A lower number indicates lower heat gain } \\
\text { thus making the windows energy-efficient. }\end{array}$ & respectively. \\
\hline Shading devices & $\begin{array}{l}\text { Extended overhangs form the shading } \\
\text { structure for all the openings. Verandas, } \\
\text { corridors and courtyard have an overhang as } \\
\text { well. } \\
\text { The roof and its overhang are made up of } \\
\text { double layered Mangalore tiles and give } \\
\text { additional insulation from heat. }\end{array}$ & $\begin{array}{l}\text { Concrete shading device running } \\
\text { horizontally on the lintel level of the } \\
\text { openings is seen. }\end{array}$ \\
\hline Material of walls & $\begin{array}{l}\text { Stabilized and fired, hollow mud bricks are } \\
\text { used for constructing walls. } \\
\text { The stabilised clay bricks with internal and } \\
\text { external cement plaster have a U-value of } \\
2.42 \text { and block heat well. }\end{array}$ & $\begin{array}{l}150 \mathrm{~mm} \text { of AAC blocks with cement } \\
\text { plaster on the interior and exterior } \\
\text { surfaces. A total U-value of } 2.4 \text { is } \\
\text { obtained. }\end{array}$ \\
\hline Material of roof & $\begin{array}{l}\text { Sloping roofs have a double layered } \\
\text { Mangalore clay tile with a U-value of } 3.6 \text {. } \\
\text { Flat roofs have mud brick - lime mortar as } \\
\text { waterproofing which also serves as an } \\
\text { insulating layer from direct heat. }\end{array}$ & $\begin{array}{l}\text { For the apartments with apartment on top } \\
\text { have RCC slab whereas the apartments } \\
\text { with terrace on top have RCC slab } \\
\text { covered with a } 300 \mathrm{~mm} \text { thick layer of coir } \\
\text { for organic farm. }\end{array}$ \\
\hline Type of roof & $\begin{array}{l}\text { Both sloping roof and flat terraces used as } \\
\text { balconies are seen throughout the house. }\end{array}$ & $\begin{array}{l}\text { Flat roof covered with a } 300 \mathrm{~mm} \text { thick } \\
\text { layer of coir for plantation. }\end{array}$ \\
\hline Water heating system & --- & $\begin{array}{l}\text { Solar panels on terrace are used for hot } \\
\text { water in all apartments for } 24 \text { hours. } \\
\text { All bathrooms are connected to the main } \\
\text { supply. }\end{array}$ \\
\hline $\begin{array}{l}\text { Natural cooling/ } \\
\text { heating system }\end{array}$ & $\begin{array}{l}\text { Apart from the very few days annually }(8 \% \\
\text { annually), the thermal comfort is maintained } \\
\text { naturally. Only few days with harsh climate } \\
\text { need energy driven air conditioning. }\end{array}$ & --- \\
\hline Ventilation & $\begin{array}{l}\text { Openings and courtyard assist ventilation and } \\
\text { air movement throughout the year. }\end{array}$ & $\begin{array}{l}\text { Windows placed aptly to achieve } 92 \% \text { of } \\
\text { annual hours of comfortable atmosphere } \\
\text { inside by using only ceiling fans. Energy } \\
\text { produced using windmills and solar } \\
\text { panels is stored in batteries and used to } \\
\text { support these appliances. }\end{array}$ \\
\hline $\begin{array}{l}\text { Efficient use of } \\
\text { daylight }\end{array}$ & $\begin{array}{l}\text { Openings and transition spaces efficiently } \\
\text { bring in diffused sunlight in all the public } \\
\text { spaces (these form } 56 \% \text { of usable space) } \\
\text { which are used mostly in daytime. }\end{array}$ & $\begin{array}{l}\text { Natural diffused daylight spread evenly } \\
\text { across all spaces used throughout the } \\
\text { day. }\end{array}$ \\
\hline Lighting system used & $\begin{array}{l}\text { An energy-saving lighting system is used } \\
\text { with low energy consuming fittings used in } \\
\text { the absence of daylight. } \\
\text { Annually only } 4790 \mathrm{KWH} \text { of energy is }\end{array}$ & $\begin{array}{l}\text { Maximum lighting fixtures used are } \\
\text { connected to the batteries which brings } \\
\text { down the total consumption of energy } \\
\text { obtained through conventional sources is } \\
4670 \mathrm{KWH} \text {. }\end{array}$ \\
\hline
\end{tabular}




\begin{tabular}{|c|c|c|}
\hline & consumed. & \\
\hline $\begin{array}{l}\text { Renewable energy } \\
\text { resources }\end{array}$ & --- & $\begin{array}{l}\text { Solar panels and windmill installed on } \\
\text { the terraces generates sufficient amount } \\
\text { of energy for the apartment and is stored } \\
\text { in the batteries in the common battery } \\
\text { room. }\end{array}$ \\
\hline $\begin{array}{l}\text { Integrated energy } \\
\text { monitoring system }\end{array}$ & --- & --- \\
\hline $\begin{array}{l}\text { Local construction } \\
\text { skills and methods }\end{array}$ & $\begin{array}{l}\text { Local labour trained to work with modified } \\
\text { products made out of local material. }\end{array}$ & $\cdots$ \\
\hline \multicolumn{3}{|l|}{ Ventilation (wind) } \\
\hline Ventilation & $\begin{array}{l}\text { A courtyard house which achieves } 82 \% \text { of } \\
\text { comfortable annual hours without consuming } \\
\text { energy. Openings placed strategically to } \\
\text { promote movement of air. }\end{array}$ & $\begin{array}{l}\text { Apt ventilation system is established with } \\
\text { openings on opposite walls wherever } \\
\text { possible. }\end{array}$ \\
\hline Cross ventilation & $\begin{array}{l}\text { Openings placed along opposite walls which } \\
\text { creates an active flow of cross ventilation. } \\
\text { Also, the double height courtyard and } \\
\text { peripheral openings create a flow of } \\
\text { horizontal ventilation due to changing } \\
\text { pressures. } \\
\text { Only 9\% of annual hours need evaporative } \\
\text { cooling measures to achieve indoor comfort. }\end{array}$ & --- \\
\hline \multicolumn{3}{|c|}{ Indoor Ambience (space) } \\
\hline Daylight & $\begin{array}{l}\text { Sufficient but diffused light pierces through } \\
\text { the openings and courtyard thus making it } \\
\text { comfortable for the users. }\end{array}$ & $\begin{array}{l}\text { Optimum diffused daylight is achieved in } \\
\text { all the spaces used in the daytime. }\end{array}$ \\
\hline Ventilation & $\begin{array}{l}80 \% \text { of the annual hours achieve two cycles } \\
\text { of air changes in a day which is a requirement } \\
\text { based on NBC } 5\end{array}$ & $\begin{array}{l}\text { Ventilation achieved with } 88 \% \text { of annual } \\
\text { hours having a change in air at least } \\
\text { twice. }\end{array}$ \\
\hline $\begin{array}{l}\text { Connectivity to } \\
\text { exterior }\end{array}$ & $\begin{array}{l}\text { Placement of huge openings based on the } \\
\text { surrounding context and function carried out } \\
\text { inside create an interactive façade, thus } \\
\text { connecting the exterior with the users living } \\
\text { inside. Semi-open spaces like peripheral } \\
\text { verandas and courtyards form a recreational } \\
\text { space for users. }\end{array}$ & $\begin{array}{l}\text { Well connected with openings and } \\
\text { farming on the terrace brings the } \\
\text { residents closer to nature. }\end{array}$ \\
\hline Thermal comfort & $\begin{array}{l}\text { Thermal comfort can be easily achieved } \\
\text { through this design and an additional use of } \\
\text { evaporative cooling for } 9 \% \text { of annual hours. }\end{array}$ & $\begin{array}{l}\text { Ambient atmosphere is achieved by } \\
\text { using minimal appliances like ceiling fan } \\
\text { in all the apartments irrespective of their } \\
\text { orientations. }\end{array}$ \\
\hline Natural finishes & $\begin{array}{l}\text { All the earthy materials used are presented in } \\
\text { its truest forms thus maintaining the original }\end{array}$ & --- \\
\hline
\end{tabular}

${ }^{5} \mathrm{NBC}$ - National Building Codes 
International Journal of Engineering Applied Sciences and Technology, 2021

Vol. 5, Issue 12, ISSN No. 2455-2143, Pages 280-290

Published Online April 2021 in IJEAST (http://www.ijeast.com)

\begin{tabular}{|c|c|c|}
\hline & finish. Walls are plastered and painted white. & \\
\hline Community lifestyle & $\begin{array}{l}\text { Traditional social and cultural elements like } \\
\text { veranda and courtyard are maintained thus } \\
\text { reinforcing the importance of customs and } \\
\text { beliefs in the community. }\end{array}$ & $\begin{array}{l}\text { Community lifestyle is revived by giving } \\
\text { the residents to involve in farming. This } \\
\text { helps residents to strengthen the bond } \\
\text { amongst the community and enhances } \\
\text { individual sense of responsibility. }\end{array}$ \\
\hline Heat Island effect & $\begin{array}{l}80 \% \text { of the unbuilt space is natural ground } \\
\text { thus capping the effect due to heating of man- } \\
\text { made surfaces and causing a negative impact } \\
\text { on the surrounding environment. }\end{array}$ & $\begin{array}{l}\text { Effect due to man-made construction } \\
\text { reduced by adding greenery on the } \\
\text { surfaces wherever possible. }\end{array}$ \\
\hline Local bio-diversity & $\begin{array}{l}\text { Local biodiversity is maintained through local } \\
\text { plantation and local materials in their original } \\
\text { finishes. }\end{array}$ & $\begin{array}{l}\text { Local biodiversity is protected as an } \\
\text { initiative to recreate farms in urban areas } \\
\text { is seen. Urban farms positively impact } \\
\text { the ecology in many ways. }\end{array}$ \\
\hline
\end{tabular}

\section{CONCLUSION}

Figure below shows three possible ways of reducing consumption of conventional energy - optimum wall window ratio which balances heat gain and air movement, design strategies promoting cross ventilation and use of renewable energy.

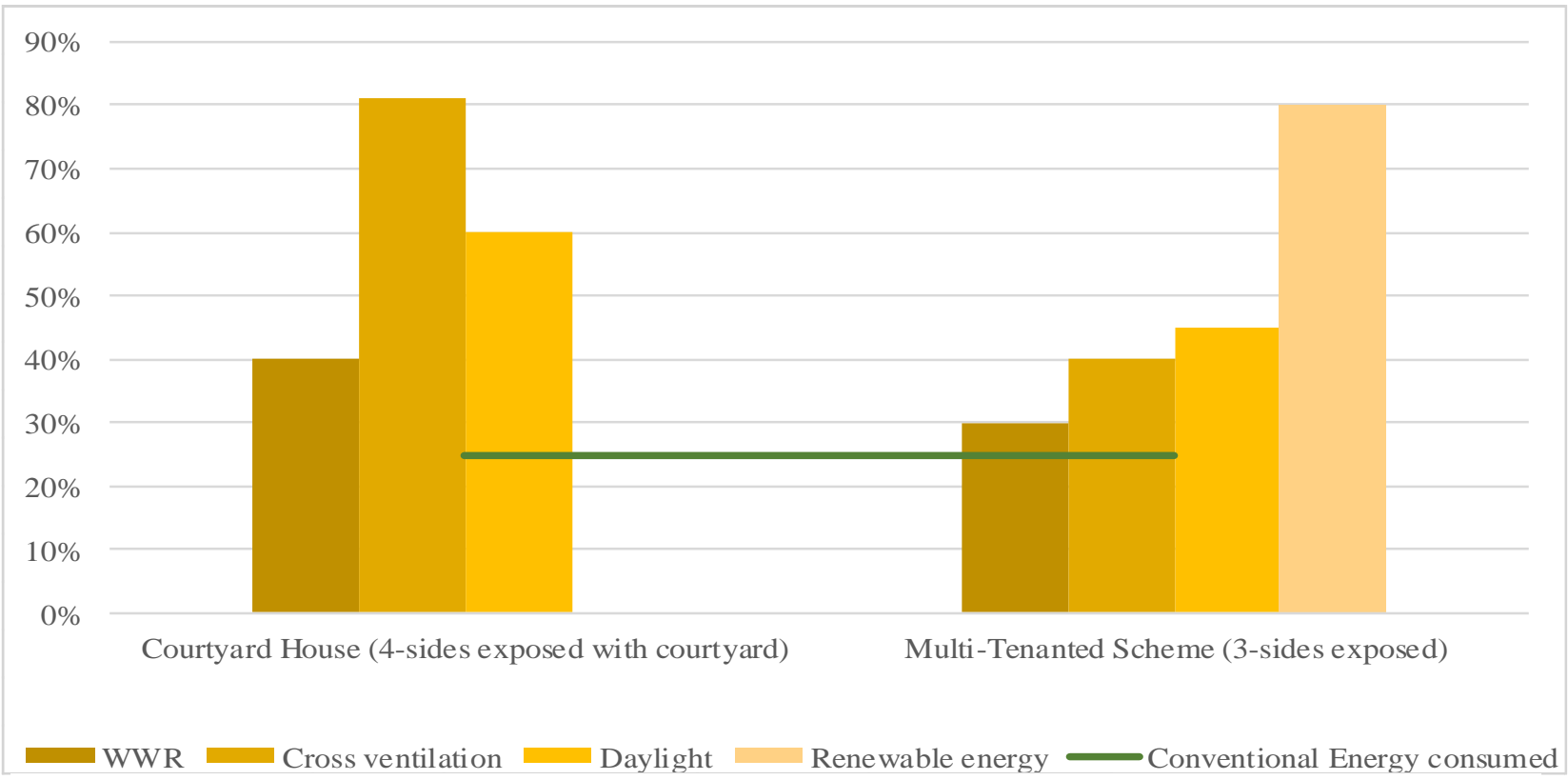

Figure 6: Comparative Analysis of openings for Ventilation, Daylight and Heat penetration.

Source: Author

Energy consumption also relies and changes based on the material used - whether local or synthetic and industrially processed - and the labour constructing the structure. Along with on-site reduction of energy consumption using local material and labour reduces an overall carbon footprint as the fuel burnt in transportation is directly proportionate to the distance travelled to get the material. 
The local labour is more informed about the geography and topographical challenges of the particular area they usually have grown up in. Giving local labour an opportunity not only brings an ease of flow in construction process but also supports the local economy and local skills which otherwise will die due to lack of demand in market. The figure below shows how the material selection impacts energy consumption.

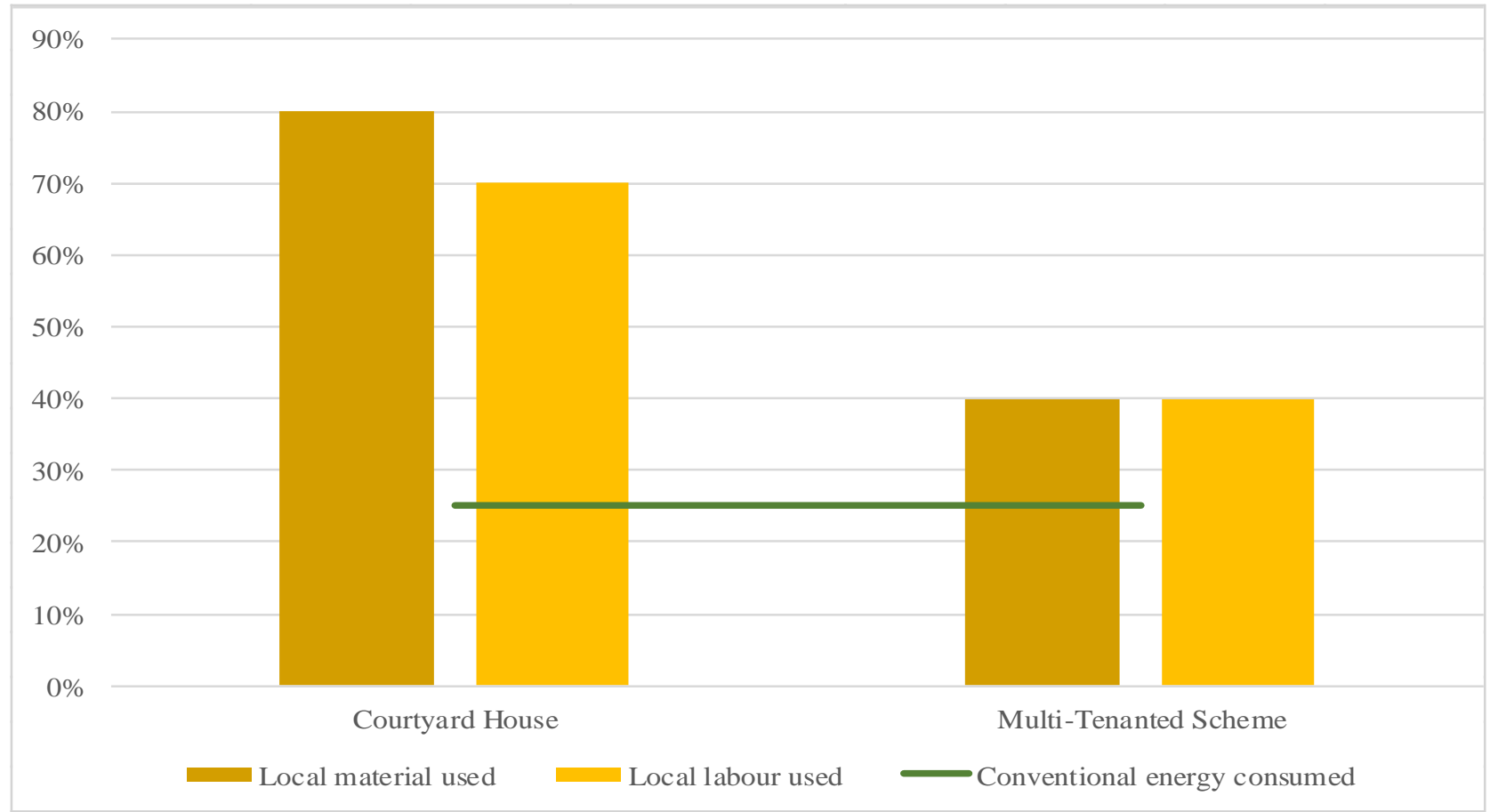

Figure 7: Comparative Analysis of local material and labour used. Source: Author

The figure below shows how the natural elements of daylight (sun), ventilation (air), External Connect (earth), and social aspect impact the indoor ambience and make it a comfortable abode for the users. A combination of two or more factors listed above in the graph helps achieve a comfortable and valuable indoor space quality. 


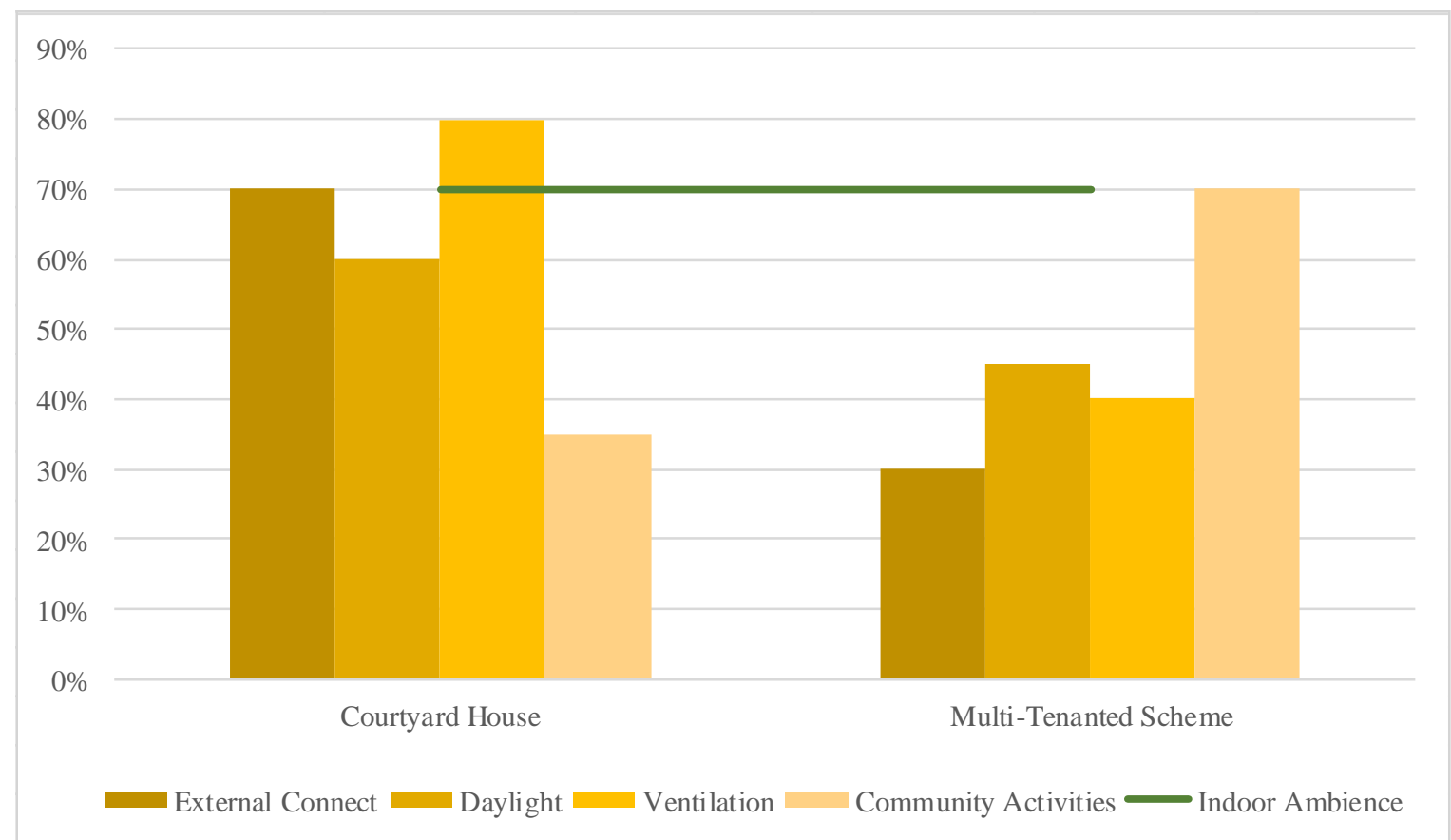

Figure 8: Comparative Analysis of Factors affecting Indoor Ambience; Source: Author

\section{REFERENCE}

1. ASHRAE. (2017). Thermal Environmnetal Conditions for Human Occupancy. ASHRAE.

2. Authority, C. E. (2019). Growth of electricity sector in Insia from 1947-2019. New Delhi: Ministry of Power, Government of India.

3. Bhati, R. K. (2015). A study of rural to urban migration. ASM'S International EJournal on ongoing research in Management and IT, 371-379.

4. Budds, D. (2019). How do buildings contribute to climate change? Curbed.

5. Chandramouli, D. C. (2011). Census of India - Rural Urban Distribution of Population. New Delhi: Registrar General \& Census Commissioner, India.

6. Dear, R. d., \& Brager, G. (2002). Thermal comfort in naturally ventilated buildings: revisions to ASHRAE Standard 55. Energy and Buildings, 549-561.
7. documentation, C. f. (2010). Impact of climate change on urban areas in India. dialogues, proposals, stories for global citizenship.

8. Kate Bode, M. W. (2007). Green building: How can passive and active systems work together? Renewable energy focus.

9. Kojima, R. (1996). Introduction: Population, Migration and Urbanization in developing countries. The Developing Economies, 349369.

10. M.Taleb, H. (2014). Using passive cooling strategies to improve thermal performance and reduce energy consumption of residential buildings in U.A.E. buildings. Science Direct, pp. 154-165.

11. Ministry of Housing and Uran Affairs. (2019). Handbook of Urban Statistics. New Delhi: Government of India press.

12. Monte, D. D. (2007). The role of cities in climate change. InfoChange.

13. Mukhopadhyay, P. (2010). India: When urban lifestyle determine the climate. A Planet for Life. 
14. Mukopadhyay, P., \& Revi, A. (2011). Climate Change and Urbanization in India. Economic and Political Weekly, pp. 59-70.

15. Nand Kishore Gupta, A. K. (2013). Quantifying Embodied Energy Using Green
Building Technologies under Affordable Housing Construction. Scientific Research An open journal of Energy Efficiency, 2(4). 